\title{
Music, Horses, and Exotic Others: Early- Modern Processions, Tournaments, and Pageants
}

\author{
RALPH P. LOCKE
}

\section{A Forgotten Category: Exoticism in Events for Large Spaces}

Exoticism can be defined as the representation-whether a direct portrayal or subtle echoes-of an Other land or people. By "Other" I mean a land or people that is both distant and different: objectively distant from Here but also understood as being different from Here in outward aspect, behavior, or cultural/religious/ethical values. Though the relationship between exoticism and music in Western culture has been widely discussed in regard to works dating from the nineteenth century onward (e.g., Puccini's Madama Butterfly), it has gone relatively unexplored regarding the centuries known nowadays as the Early Modern period (that is: ca. 1500-1800). Indeed, many music histories and reference books begin their discussion of exoticism with the alla turca (or "Janissary") style, a collection of traits used in such late eighteenth-century works as Mozart's Die Entfiihrung aus dem Serail (The Abduction from the Harem; 1782) and his "Rondo alla turca" (the concluding movement of his Sonata in A Major/Minor, K. 331, ca. 1783). ${ }^{1}$

Exotic conceptions were very much an active factor in numerous spheres of musical life during the several hundred years before Mozart. Most prominently, opera-just a few decades after its founding around 1600 - began to portray such distant and culturally unfamiliar situations as a Turkish harem, an ancient Persian armed camp, the Chinese imperial royal court, Aztec Mexico, and Incan Peru. ${ }^{2}$ Exotic conceptions in early opera (and related genres, including the comédies-ballets of Molière and Lully) are now relatively familiar thanks to recordings, staged productions, and DVDs of such major works as Handel's Giulio Cesare in Egitto (Julius Caesar in Egypt; 1724), Mozart's aforementioned Entfiuhrung, and the Turkish

\footnotetext{
The present article develops further some principles first explored in the author's books of 2009 and 2015 (see notes 1 and 2), but in regard to a type of cultural product not discussed there. The author wishes to thank Anthony M. Cummings, Kelly Harness, Kate van Orden, and, for help with the translation from the Russian in note 3, Paul Bushkovitch.

${ }^{1}$ The first of my two books on this broad topic, Musical Exoticism: Images and Reflections (Cambridge: Cambridge University Press, 2009), focuses on manifestations of the exotic in music from around 1700 onward, in instrumental works (e.g., Mozart's Rondo "alla turca," Rimsky-Korsakov's Sheherazade) and vocal and/or dramatic ones (Puccini's Madama Butterfly, Bernstein's West Side Story, the film scores to the Bob Hope and Bing Crosby "Road" movies). The discussion of alla turca style (Musical Exoticism, 123-26) includes a detailed list of frequently used style traits. Mozart's K. 331, it now seems likely, was composed in 1783 (rather than several years earlier, as was sometimes thought); see the evidence provided by Balász Mikusi's recent discovery of a page of the manuscript: "Wolfgang Amadé Mozart: K. 331 Sonata in A Major," at the website of the National Széchényi Library, Budapest: http://mozart.oszk.hu/index_en.html\#home.

${ }^{2}$ For an extensive discussion of exotic elements in various streams of opera, see Locke, Music and the Exotic from the Renaissance to Mozart (Cambridge: Cambridge University Press, 2015), 208-323, also 187-91 (sacred opera). That book, a "prequel" to my Musical Exoticism, treats the years 1500-1800 and surveys a wide range of genres in addition to opera, such as oratorio, broadside ballad, courtly ballet, theatrical dance (including balli in Italian-language operas), and foreign dance pieces for lute. The book brings further discussion of the uses of alla turca in works of the eighteenth and early nineteenth centuries: pp. 4, 8, 18, 20, 23-24, 26-27, 32, 36, 176, 197, 279, 283, 299-301, 303, and 308-20.
} 
scene in Molière and Lully's Le bourgeois gentilhomme (roughly translated: The Foolish Middle-Class Man Who Let Himself Be Persuaded That He Was a Noble; 1670).

Much less familiar to most of us today are the representations of the exotic in certain types of cultural products and events that, though they made prominent use of music, are not normally described as belonging to a musical "genre." I have in mind, particularly, courtly ballets, danced (mimed, etc.) intermedi, and large-scale events such as tournaments, processions, and pageants. ${ }^{3}$ These three types of music-undergirded cultural products/events were already well established before opera came into being, then continued in parallel with opera for many years, and were mostly created by a given court or government, often with a frank or barely disguised propagandistic aim. Thus all three types should be of great interest to any comprehensive exploration of "music in society"-and specifically "music and politics" — as should the ways that "the exotic" was represented within them.

In my recent book Music and the Exotic from the Renaissance to Mozart I discuss the first two types, namely ballets and intermedi. ${ }^{4}$ The present article focuses on the third type: events that tended to be held outdoors (or in a large hall or courtyard) and that often-because of this-were able to involve riders on horseback. Some such large-scale events occurred in relative privacy within the protected grounds of a royal palace. Others occurred in full public view, notably when a procession moved through the streets and public squares of a major city.

Large-scale events of these sorts have, to be sure, been studied by specialists interested in how ceremonies, horsemanship, and music were used by aristocratic rulers-often in conjunction with church officials-to symbolize and consolidate their power. By contrast, the frequent representation of exotic lands and peoples within these events has gone almost without comment in scholarly studies, even when those studies do mention, in passing, this or that exotic feature. The net result is that events of this "largescale" kind have not entered into most discussions of "music and the exotic." ${ }^{5}$ Nor, as already noted, have such events entered into discussions of music's relationship to politics, or, more specifically, to the ways in which international, cultural, and religious tensions were enacted on occasions that were more or less public. The present article aims to give a sense of how frequently_and by what means-concepts and images of the exotic were manifested in these large-scale (and often horse-involving) events and what role the music played in supporting such concepts and images.

A number of major historical developments during the years 1500-1800 shaped the ways in which influential Europeans-including governmental and religious officials but also writers, musicians, and their often high-status readers and listeners - thought about the world beyond their doorstep and created images of it in the public sphere:

\footnotetext{
${ }^{3}$ Two relatively late instances produced pieces that remain familiar to lovers of classical music today. 1) Beethoven wrote the incidental music for Die Ruinen von Athen (The Ruins of Athens), an 1811 celebratory pageant written by the Austro-Hungarian court poet August von Kotzebue. In one scene, numerous Turkish soldiers arrive onstage waving their sabers and then gradually march off, to the accompaniment of Beethoven's “Turkish March" (a tuneful piece that is well known today). 2) In 1880, Alexander Borodin composed his orchestral piece V srednye ̌ Azii (In Central Asia; more generally called, in English, In the Steppes of Central Asia) as a musical backdrop for an intended tableau vivant celebrating the "peaceful" subjugation of that region by the troops of the Russian emperor, Alexander II. The tableau vivant ended up being cancelled, but Borodin's music became a staple of the concert repertory. Often the concert organizers—and CD manufacturers_print, in the program book or CD booklet, Borodin's words explaining that the piece depicts a caravan (of, presumably, Muslim traders) moving "trustingly and without fear...under the protection of Russian armed force."

${ }^{4}$ Locke, Music and the Exotic from the Renaissance to Mozart, 139-64 and 174-80 (intermedi and operatic balli) and 165-68 (ballets); also 92-93 (brief mention of pageants and processions).

${ }^{5}$ See W. Anthony Sheppard's annotated bibliography (now in its second edition) for the topic "Exoticism" in the Music subject area of Oxford Bibliographies: http://www.oxfordbibliographies.com/view/document/obo-9780199757824/obo9780199757824-0123.xml? rskey $=$ hA78AR\&result $=45$.
} 
- During these years, Europe encountered ever more far-flung territories and peoples: through improved sea travel, exploration, commerce, colonization, and, sometimes, war. The era saw conquest of the entire Western Hemisphere, growing trade with-and imperial outposts in-India and parts of East Asia, and fierce struggle among several European nations (notably Spain, Portugal, Britain, France, the Netherlands, and, briefly, Austria and Sweden) for the profit that control of trade and overseas settlements could bring.

- The time period also saw recurring struggles between Europe and the Ottoman Empire: in southeastern Europe (a vast territory that the Ottomans successfully conquered and held for hundreds of years), in central Europe (e.g., the Ottomans' two lengthy, if ultimately unsuccessful, sieges of Vienna, in 1529 and 1683), and on major Mediterranean islandsnotably Corsica, Crete, Cyprus, Sicily, and Malta - that were valued by the Ottomans but also by the Venetians and others as stopping-places for merchant ships.

- Increased literacy and mobility enabled individuals to gain definite impressions of individuals and groups living elsewhere in Europe. This included learning about life and customs in territories that were relatively nearby but had remained heavily rural. To an aristocrat in a palace in Russia or Habsburg Austria, say, or to a successful merchant living in a sizeable city (such as Moscow or Vienna), rural folk who lived only a few hours' travel away may well have seemed more unfamiliar in manners and cultural values-more primitive or laughable, more not-Us - than aristocrats or city folk living in distant lands who were more comparable to Us in social status, education, and cultural background (e.g., English merchants and doctors, or Parisian clergymen and countesses). Thus one should not be surprised to find that some of the same procedures that works of music, literature, and art employed to exoticize a truly distant land could also be applied to people living in villages or in the mountains: people understood as living in a social and cultural world that was understood as less civilized-more primitive-than the world of the educated reader or big-city audience member.

It was in the context of these major and interrelated developments that the court cultures of numerous European countries developed pageants, processions, tournaments, and equestrian ballets that sometimes engaged in overt-if also stylized and often rigidly stereotyped—ritual enactment of diverse foreign places, peoples, and customs and that these sometimes evoked more nearby rural customs as well. Such events were, as mentioned above, often held outdoors or in large indoor spaces. They thus made heavy use of visual elements and physical movement: elements that could be "read" by a wide and sometimes varied throng of onlookers, and could be described in detail by court chroniclers in commemorative brochures or by visiting dignitaries in private diplomatic correspondence.

Some of these large-scale events were enriched with singing, declaimed poetry (including prefatory panegyrics lauding the ruler in question), dance, instrumental music, and celebratory choruses. The sung and spoken words helped to clarify the meaning of the costumes and other visual elements, and were often preserved and disseminated in the aforementioned commemorative brochures. ${ }^{6}$ Other such events made little or no use of words-except perhaps on a banner or two, or on a temporarily erected gateway-and conveyed their intended meanings primarily through visual means. Still, most such events seem to have incorporated instrumental music_-such as brass fanfares - to focus the viewer's attention and to convey a

\footnotetext{
${ }^{6}$ See, for example, the public processions and celebrations in Rome and Florence organized by, or honoring, Pope Leo X, discussed in Anthony M. Cummings, The Lion's Ear: Pope Leo X, the Renaissance Papacy, and Music (Ann Arbor: University of Michigan Press, 2012), 13-44. Cummings argues that some of these events involved indirect allusions-through the moresca dancing and pretend-fighting-to the Turkish/Muslim enemy.
} 
sense of the lord's or regime's grandeur and power.

The music performed at such events was most often instrumental and dance- or march-oriented. In some cases, it was played by a single trumpet or drum; in others, the music could involve numerous players: say, a string orchestra reinforced with multiple lutes and keyboard instruments. In various ways, the exoticizing aspects in these rather unique blendings of court ritual and music theater-as also in danced intermedi, opera balli, and full-length court ballets-give evidence of a deep cultural fascination with (fear of, admiration for, and so on) exotic ethnicity and a love for musical display and expression. Yet, as we shall see, exoticist representation and musical mastery were still often kept somewhat separate, whereas they would be increasingly combined and elaborated, to powerful effect, in new musicodramatic genresnotably opera, dramatic oratorio, and theatrical ballet - that arose in the course of the seventeenth and eighteenth centuries. ${ }^{7}$

The remaining sections of the present article explore how music was brought into play when processions, tournaments, and equestrian ballets engaged in enacted (proto-theatrical) portrayals of exotic Others. They also evoke-in more detail than was possible in the introductory remarks above-certain political, cultural, literary, and other contexts that shaped how the portrayals were understood. In order to keep the discussion relatively concrete, the main instances come from a particularly well-documented era and interconnected (double-)region: fifteenth- and sixteenth-century France and Italy. One extended occasion, unusually well documented, will be discussed in depth: the multi-day festival that was mounted in Bayonne in 1565 on the occasion of the visit to that city by Charles IX and his mother, Catherine de' Medici. Documents of the period rarely mention the specific music that was performed at a given largescale event of the sort being examined here (e.g., a procession or tournament). For this reason, we will, for the most part, defer until the article's final sections a discussion of the specific kinds of music that were probably used on such occasions.

\section{Tournaments, Horse Ballets, and Royal "Receptions"}

The earliest European exotic celebrations of which we have some detailed evidence had been-as Miriam K. Whaples puts it—not so much "aesthetic performances" as "violent games," a clear instance being "fourteenth-century exhibition tourneys [i.e. tournaments] where knights jousted against others dressed as 'Saracens' or 'Moors."” At a 1378 banquet at the French court in honor of Emperor Charles IV, a model of the Jerusalem citadel was wheeled in, and "Crusaders" arrived by boat, then disembarked to fight "Saracens" to the death. ${ }^{9}$ (The term Saracens-which is related to the modern place-name Syriareferred largely to Arabs and Mamluks, who were seen by Christian Europe as unlawful rulers of large regions in the Middle East, Northern Africa, and on the Iberian Peninsula.) Readers today—shaped by a scientific attitude and by the aesthetic norms of cinematic "realism" - may wonder whether the boat in this re-enactment was a real vessel or, say, a few slats of painted wood carried by the "Crusaders" themselves and whether it pulled up to the edge of a river (or a man-made pond) or, rather, was surrounded by a

\footnotetext{
${ }^{7}$ See n. 4 above.

${ }^{8}$ Miriam K. Whaples, "Early Exoticism Revisited," in Jonathan Bellman, ed., The Exotic in Western Music (Boston: Northeastern University Press, 1998), 3-25, 307-13 (here 5).

${ }^{9}$ Daniel Heartz, "Un divertissement de palais pour Charles Quint à Binche," in Fêtes et cérémonies au temps de Charles Quint, ed. Jean Jacquot, vol. 2 of Les Fêtes de la Renaissance (Paris: Editions du Centre national de la recherche scientifique, 1960), 329-40 (here 334). Heartz also mentions a Christian/Saracen "combat" in honor of the 1389 entry of Isabelle of Bavaria into Paris.
} 
theatrical device indicating waves (such as stagehands swaying horizontal strips of blue cloth). But, as scholars today stress, the organizers of court festivals aimed at blurring the line between reality and artifice and were often judged as having succeeded at doing so. ${ }^{10}$ The costuming during this particular enactment of the supposed freeing of Jerusalem from Muslim control was surely emblematic rather than historically accurate: the main point was to establish a contrast between an Us and a Them (that is, a religious and geopolitical Other).

By the late sixteenth century, parallel to the tournaments themselves, two related traditions had arisen: equestrian ballets and equestrian processions. The former-also known today as "horse ballets"were exhibitions of what we might call "synchronized and highly patterned equestrian movement." Such exhibitions required much practice and rehearsal (perhaps with whatever music was likely to be used in the actual performance) and usually took place on a fenced-in tournament field. By contrast, equestrian processions required little special preparation and-being more linear-often flowed through the streets of a town, like a modern-day parade. No doubt, though, some processions took place, like the ballets, on an open field rimmed with onlookers or at least reached their culmination on such a field. A procession that involved wheeled vehicles-pulled, of course, by yet more horses-was generally called a carrousel. A carrousel was sometimes performed as an elaborate opening or closing event to a tournament. The term derives from the French carrosse or the Italian carrozza, i.e., a horse-drawn carriage or other wheeled vehicle, often richly decorated and carrying people symbolically costumed. Such a vehicle is nowadays often referred to by historians as a "festival car."

These various presentational equestrian events were inspired by ancient Greek descriptions, especially in Xenophon, of how to train horses to parade. In the most demanding of these events-the equestrian ballets-noblemen rode horses that had been trained to step high and to execute geometric figures. The noblemen's squires were themselves of noble birth and thus often participated on horseback as well, though their horses might not step quite so high. The figures that the horses inscribed in equestrian ballets were often roughly analogous to the floor patterns generated by dancers in courtly ballets of the same era. And, like those dance patterns, they were apparently understood (at least by certain writers of the time) as reflecting visible features in the natural world-such as how flocks of large birds fly in lines and V's - and also as reflecting basic principles of order that undergird the cosmos. ${ }^{11}$

All equestrian events—-parades, tournaments, elaborate ballets—had one central point in common: they allowed a rider to practice, and then demonstrate, his self-control, his battle-readiness_and that of his horse-and, by extension, his "ability to rule in society." 12 When guests were present, especially foreigners (or restive nobles from nearby), equestrian events had the further advantage of inciting

\footnotetext{
${ }^{10}$ On artifice/stylization as a desirable quality, see Marie Thérèse Bouquet-Boyer, "Les éléments marins dans les spectacles à la cour de Savoie, 1585-1628," in The Influence of Italian Entertainments on Sixteenth-and Seventeenth-Century Music Theatre in France, Savoy and England, edited by Marie-Claude Canova-Green and Francesca Chiarelli (Lewiston NY: Edwin Mellen Press, 2000), 53-68 (here 65).

${ }^{11}$ For an account of "pyrrhic" (i.e., warlike) dances by Moors, savages, and satyrs, see Maxime Gaume, ed., La triomphante entrée de tresillustre dame Madame Magdeleine de la Rochefoucaud ... (Saint-Étienne: Presses de l'Université de Saint-Étienne, 1976), 33-34. See also the summary of Gaume's main source-an account of a religio-political moresque of 1583-in Locke, Music and the Exotic from the Renaissance to Mozart, 152-53. On horse ballets, pyrrhics, the militaristic contexts of the Jesuits, and many related topics, see Kate van Orden, Music, Discipline, and Arms in Early Modern France (Chicago: University of Chicago Press, 2005), and Paolo Fabbri, ed., Musica in torneo nell'Italia del Seicento (Lucca: Libreria Musicale Italiana, 1999). On squires in horse ballets, see, for example, van Orden, Music, 271. On Platonic aspects of courtly dancing (including parallels to the perceived orderliness of the universe), see Mary Chan, Music in the Theatre of Ben Fonson (Oxford: Clarendon Press, 1980), 126-31.

${ }^{12}$ Van Orden, Music, 252-53, 257, and (quoted words) van Orden's narration on a one-minute video at the website for her book: http://press.uchicago.edu/ucp/books/book/chicago/M/bo3533738.html.
} 
admiration for the lord or ruler who was hosting the occasion and perhaps also of inciting some fear of his ability to "activate this potential [for braving a field-battle], if necessary." 13 In the equestrian ballets, in particular, noblemen and their squires demonstrated the ability to move their steeds in controlled and coordinated fashion, reflecting a shift in warfare from the heavily armed individual knight to fleet battalions of cavalry. ${ }^{14}$

The figure of the hated Turk or Moor was essential to the training of horsemen. (The word "Moor" was sometimes used as a catchall term for any person from a Muslim-controlled land, whether Turk, Arab, or Mamluk; other times it meant a very dark-skinned individual of, ultimately, sub-Saharan African origin-or even someone from further away: say, the Indian subcontinent.) In various European countries, from the sixteenth century (or even earlier) through the eighteenth, jousts of man against man—based on traditional battlefield combat—began to be replaced by "running" at a solid target and smashing one's lance against it, or attacking it with some other implement, e.g., sword, pistol, or ax. The target was usually a full-sized wooden statue of a Turk (or Moor) —with battle helmet and at least somewhat dark skin—or else just his head, though sometimes it was also another fearful creature, such as a dragon. ${ }^{15}$

Many equestrian events were accompanied by music of an outdoor sort, such as marches for wind instruments. The music clearly had multiple functions: it drew the attention of the onlookers, glorified the noble riders, and helped the riders and horses maintain coordination and a steady pace-a matter that was particularly important in equestrian ballets. (Loud wind instruments playing strongly rhythmic tunes could be heard by the riders and their mounts above the noise of the tromping horses' hooves.) Little is known about what specific musical selections were offered at any given event, nor what precise types of instruments were employed. We shall discuss this matter more extensively in the sections below about ceremonies in Bayonne in 1565. Still, it is important to stress that music was most often a crucial component in these events, helping to motivate and coordinate the actions of the horses and their riders.

The costumes were often crucial as well. In jousts and tournaments, the "contending" nobles often paired off in various national or ethnic costumes, however accurate or freely imagined. In the 1378 tournament discussed above, the distinction between Westerners and Easterners (or, put differently, between Christians and Muslims) was probably established by relatively simple means: banners with recognizable insignia (e.g., cross vs. crescent moon) or different colored plumes in the men's helmets. In time, though, portrayal of groups and nations during jousts, tournaments, processions, and the like seems to have become increasingly distinct. These visual portrayals were often based at least in part on the travel reports-again, often highly selective or misleading — that were being written by explorers, missionaries, and merchants and that often contained (highly approximate) illustrations.

Thus, in an equestrian ballet of 1662, the Duc d'Orléans (brother of King Louis XIV) appeared as "king of Persia," decked out in a bizarrely elaborate costume that included an assemblage of enormous pompom flowers (or imitations thereof) atop his helmet. Presumably his head-garden was a reference to

\footnotetext{
${ }^{13}$ Kelly Harness, Echoes of Women's Voices: Music, Art, and Female Patronage in Early Modern Florence (Chicago: University of Chicago Press, 2006), 147 (in regard to Florentine cavaliers and Medici princes in the early seventeenth century).

${ }^{14}$ Van Orden, Music, 279.

${ }^{15}$ Helen Watanabe-O'Kelly, Triumphal Shews: Tournaments at German-Speaking Courts in Their European Context 1560-1730 (Berlin: Gebr. Mann Verlag, 1992), 18-23. In her Fig. 9 (a Ritterspiel from Leipzig, 1617), a black-faced helmeted "head," placed on the ground, is under imminent attack. Similarly, an illustration of a tournament outdoors at the Palazzo Valfonda, 1600 , shows a helmeted statue ("quintain" was the term, from ancient Roman military terminology) at the moment of impact from a rider's lance, and the statue is black-faced-Roy Strong, Art and Power: Renaissance Festivals, 1450-1650 (Woodbridge: Boydell Press, 1984), Fig. 97.
} 
long-standing associations between the Middle East and flowers: e.g., the gardens in Song of Songs; or the many-colored tulips that, imported from Turkey, began to grace Dutch and French homes and to figure prominently in still-life paintings. ${ }^{16}$ This duke's horse, too, was decked out: its mane tied with a number of decorative bows and its sides tightly swathed in decorative cloth gathered into gracious scooping curves. That all of this had, one suspects, little to do with actual customs in Persia was beside the point. The aim was to show Middle Easterners as besotted with luxury in ways that were visibly different from those favored by the ruling classes in Europe.

Still, there were clearly times when concrete racial and ethnic features were pointedly invoked. Two helmet-visors survive from the court of Holy Roman Emperor Ferdinand I. (See Figure 1. A visor was attached to a helmet to protect the riders face during combat. Hinged at both sides, it could be lifted to allow the rider to reveal his identity or simply catch a breath. $)^{17}$ The two visors, according to the Vienna museum that now owns them, belonged to Archduke Ferdinand II of Austria (1529-95). They were fashioned, perhaps in the 1550s, in Prague, a city that-though we now think of it primarily as the capital of the Czech-speaking lands-was a major center of the German-speaking world for centuries and indeed would serve as the capital of the Habsburg Empire during the years 1583-1611. According to the museum's description, the visor with very dark skin, a broad nose, some gold teeth, and chin whiskers represents a Moor (by which term the authors of the description seem to mean a sub-Saharan African); and the one with yellow-brown skin, a somewhat hooked nose, and a wide mustache, represents a Turk (i.e., an Ottoman soldier, perhaps from elsewhere in the Middle East, since the Ottoman army conscripted soldiers from lands that it conquered). ${ }^{18}$ Similarly, two illustrations showing post-tournament festivitiesin a manuscript compiled (a half-century earlier) at the request of Emperor Maximilian I-show, respectively, men in very dark or netted face-masks plus black caps with a feather (i.e., sub-Saharans?) and men wearing clothing and masks apparently meant to make them look like Turks (they wear broad turbans and the masks have medium-dark skin and hooked noses). ${ }^{19}$

Exotic animals and exotically clad servants could likewise enhance the scene, thereby helping to turn a simple joust or tournament into a semi-theatrical occasion that reminded viewers of the various distant lands that Europe was coming to know, fight over, and in many cases control. The program written in advance for festivities surrounding the wedding of the Duc de Joyeuse in September 1581 gives a vivid description of a planned "running at a golden ring" by three men (dressed in white, on black horses) and three women (dressed in black, on white horses). All riders and mounts were further decorated in silver and gold, as were their accompanying pages and damsels.

Each of the six [female and male riders] will have, to carry his or her lance [sa lance], a king of a foreign country, in chains [roy d'estrange pays enchainé], and they will [all] be accompanied by a

\footnotetext{
${ }^{16}$ This association would continue: for example, in the third entrée of Rameau's Les Indes galantes (1735-36), "Les fleurs: fête persane" ("The Persian Flower-Festival").

${ }^{17}$ Photos of these two helmet-visors are also reproduced in Barbara Ravelhofer, The Early Stuart Masque: Dance, Costume, and Music (Oxford: Oxford University Press, 2006), 233. Ravelhofer incorrectly labels them "vizards." A vizard was a mask held in front of the face (often by a stick at the bottom) and primarily used by women when walking or traveling.

${ }^{18}$ Hofjagd- und Rüstkammer, Kunsthistorisches Museum, Vienna; inventory nos. B65 andB62. The two visors were constructed from iron (painted), leather, and horsehair. Multiple small holes in the painted "eyes" allowed the fighter to see what was directly in front of him. Both visors were-according to the Museum-used by Hussars in a tournament that was performed, at the archduke's request, in Prague on Shrove Tuesday, 1557. The participants were divided into two contending parties: Christian knights and Hungarians in one, Turks and Moors in the other.

${ }^{19}$ These illustrations were painted for the never-completed illustrated book Freydal (1502-15), about the young Maximilian's many (real or imagined) triumphs in jousts. Plates 183 and 112 from that book, discussed above, are reproduced as Figures 6.5 and 6.4 in Locke, Music and the Exotic from the Renaissance to Mozart, 122 and 121.
} 
speech [or: "tale"] in a foreign, incomprehensible language [récit en langue estrangère non entendue], with some elaborate music sung by six Moors [quelque musique extravagante récitée par six Mores], [who will be] carried in a litter on a camel, or in a tower atop an elephant. ${ }^{20}$

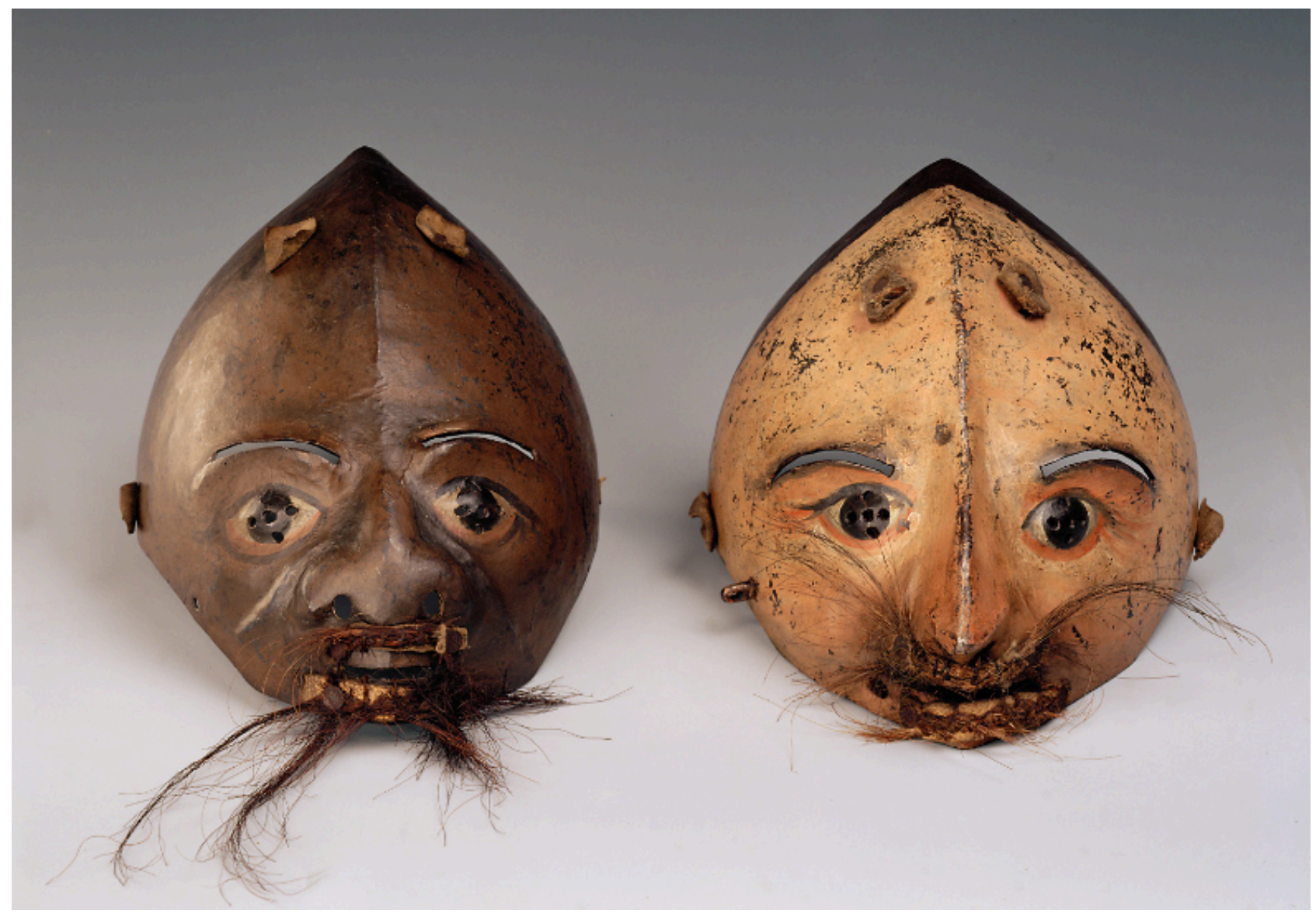

Figure 1. Two helmet-visors made in Prague, made in Prague, ca. 1555. The one of the left was designed to resemble a sub-Saharan "Moor" with dark skin, broad nose, untrimmed whiskers, and some gold teeth. The one on the right was designed to resemble the face of a "Turk," with light-brown skin-tone and a somewhat hooked nose. A visor (sometimes spelled vizor) was attached to a helmet to protect a fighter's eyes during a joust or battle; it could be raised when not in use to reveal the individual's identity and facilitate breathing. The visors shown here were constructed from iron (painted), leather, and horsehair. Multiple small holes in the painted "eyes" allowed the fighter to see what was directly in front of him. Both visors were-according to the Vienna museum that owns them-property of Archduke Ferdinand II of Austria (1529-95), son of Emperor Ferdinand I. The straight ridge along the top of the "skull" of each visor was presumably intended to help deflect attack by an opponent's weapon. It bears some resemblance to the ridge seen in illustrations of certain traditional helmet shapes, e.g., those widely associated with Varangians. For higher-resolution image, go to http://www.khm.at/objektdb/detail/373597/. (Hofjagd- und Rüstkammer, Kunsthistorisches Museum, Vienna, inventory nos. B65 and B62.)

\footnotetext{
${ }^{20}$ Frances A. Yates, “Poésie et musique dans les 'Magnificences' au mariage du duc de Joyeuse, Paris, 1581," in Musique et poésie au XVI siècle: Paris 30 juin-4 juillet 1953 (Paris: Centre national de recherche scientifique, 1954), 242-64 (here 257-58). The phrase musique extravagante may mean here something like "astonishingly unusual [or: elaborate] music." The term récit may imply a tale or narrative.
} 
The inclusion of a full-sized elephant on this and other such occasions-whether it was real or artificial is rarely made clear-is an obvious allusion to Africa or Asia. In one of the famous Valois tapestries from the late sixteenth century, a realistic-looking elephant, standing on a round platform, is attacked from all sides by groups of warriors. The attackers, some of whom are on horseback, include wild Scotsmen and turbaned Turks, but also ancient Romans and what art historian Frances Yates describes as "knights of some semi-ecclesiastical military order." (These latter are presumably an allusion to the Crusades of centuries earlier.) The elephant is being defended by a small circle of warriors at the edges of the circular platform and by yet more fighters crammed into a double-deck tower on the elephant's back. ${ }^{21}$ That the warriors defending the elephant have no horses may, I propose, have been meant to recall, in part, the Greek conquest of India in 326 BC, during which Alexander the Great's troops, on well-trained horses, easily outfought the elephant-riding Indians. ${ }^{22}$

Equestrian extravaganzas of various sorts-often invoking Turks, Moors, or other notably "different" foreigners-occurred in a number of locales, from Portugal and Crete to Norway and Poland. ${ }^{23}$ At the courts of northern Italy-especially the Medici court in Florence-the horses were trained to execute particularly elaborate maneuvers. ${ }^{24}$ The latter practices soon moved north into cities (such as Munich and Vienna) that maintained close political and religious connections to the Italian peninsula and, more specifically, to the church and pope in Rome.

Not to be outdone, the French court began putting on grand spectacles of its own, especially after Catarina (de' Medici, of the renowned Florentine family) married Henri II, becoming Queen Catherine ("de Médicis," though historians writing in English largely use the Italian form of her family name). Fortunately for posterity, the French extravaganzas-including many horse-based events-were often documented profusely in word and image.

Some of the most elaborate French pageants that involved music and exotic matter occurred in the context of a "royal tour" (also known as a "royal progress"). In many countries during the Early Modern era, the monarch and members of his or her court would make an extended tour of the realm. Often this occurred at the beginning of a king's reign. As Kate van Orden explains, "Paris and provincial capitals rolled out the red carpet for the new sovereign, hoping through their tributes to gently instruct young monarchs on their obligations even while securing future favor." 25

\footnotetext{
${ }^{21}$ Frances A. Yates, The Valois Tapestries (London: Warburg Institute, University of London, 1959), 8, 91, and Plate VIII. The occasion for this tapestry (whose nickname, by art historians, is Elephant), which features François, Duke of Anjou, is apparently not known. François was the youngest brother of Charles IX, who in the meantime had died and been succeeded as king by the middle brother (thenceforth known as Henri III).

${ }^{22}$ This episode, widely known from history books, became the seed for Metastasio's opera libretto Alessandro nell'Indie, best known today through operas freely based on it by Handel and Hasse. See my article "Alexander der Grosse und der indische Raja Puru: Exotik in einem Libretto Metastasios und in darauf basierenden Opern von Hasse und von Händel," trans. Michelle Miles and Ingo Maerker, in Fremde Helden auf europäischen Bühnen 1600-1900, ed. Achim Aurnhammer and Barbara Korte, vol. 6 in the series Helden-Heroisierungen_Heroismen (Würzburg: Ergon, 2016), 127-44. My original English version, which is somewhat fuller and adds an illustration and ten musical examples, has now appeared: "Alexander the Great and the Indian Rajah Puru: Exoticism in a Metastasio Libretto As Set by Hasse and by Handel," Revue de musicologie 102 (2016), no. 2, pp. 275-318. The shorter version is also available in Italian translation as "Alessandro Magno e il Ragià indiano Puru: Esotismo in un libretto di Metastasio nelle realizzazioni di Hasse e Handel," trans. Luana Salvarni, Musica/Realtà, no. 110 (July 2016): 99-123.

${ }^{23}$ A massive overview, bringing together much new or previously scattered information, is offered in Pierre Béhar and Helen Watanabe-O'Kelly, eds., Spectaculum Europaeum: Theatre and Spectacle in Europe (1580-1750) / Histoire du spectacle en Europe (1580-1750) (Wiesbaden: Harrassowitz Verlag, 1999).

${ }^{24}$ A. M. Nagler, Theatre Festivals of the Medici, 1539-1637, trans. George Hickenlooper (New Haven, Yale University Press, 1964).

${ }^{25}$ Van Orden, Music, 175; cf. Clifford Geertz, Local Knowledge: Further Essays in Interpretive Anthropology, ${ }^{\text {rd }}$ ed. (New York:
} 
A royal tour often included stays in cities at the extremities of the realm, thereby emphasizing the court's reach and sway. For France, the extremities included the problematic Rouen (capital city of Normandy), which for some years in the late sixteenth century was a center of Protestant rebellion. More generally, each new French king seems to have felt a need to assert his authority over the provincial nobles. Some of them had "foreign" manners: it was often observed that, unlike good Parisian courtiers, they did not conceal strong emotions. Some of them also maintained private armies. ${ }^{26}$ France was, at this time, not the fully unified nation that it would become a century later. It is helpful to remember that Provence took a month or more to reach, on foot, from the north of France. ${ }^{27}$ Provençal, more a language of its own than a dialect of French, remained widespread throughout the era of the Bourbon monarchs and beyond (to the consternation of government officials) ${ }^{28}$

Religion played a crucial role in political and cultural developments within France (and of course elsewhere as well). During the sixteenth century, the French royal family attempted to negotiate between a traditionally exclusivist version of Catholicism-favored by the Spanish crown and by various extreme French factions (most prominently, the Catholic League) — and the demands of the young and growing Protestant movement. The French rulers' moderation in this regard was spectacularly inconsistent: Henri II and Catherine condoned (or perhaps encouraged) such practices as burning Huguenots alive and cutting their tongues out. In August 1572—-during the reign of the couple's son Charles IX-government forces carried out what historian Mack P. Holt calls "the coordinated murder of several dozen Huguenot leaders," part of a series of events that is generally referred to, in simplified manner, as "the Saint Bartholomew's Day Massacre." 29

Perhaps surprisingly to observers today, this emphasis on (and growing struggle over) religious orthodoxy did not prevent European court cultures from continuing the Renaissance-era tradition of representing, and praising, non-Christian figures in paintings, statuary, plays, and the like. ${ }^{30}$ Court culture maintained a frequent, even frank emphasis on the delights of the flesh; the result was poems, sculptures, and the like that stand in strong contrast to the spirit of modesty and self-denial in much specifically Christian art of the era. ${ }^{31}$ No surprise, then, that the ancient gods and other mythological creatures, as well as numerous distinguished ancient heroes and figures from Greek and Roman mythology made

Basic Books, 2000), 125.

${ }^{26}$ On the disparity between manners in the centralized French court (wittily recorded by La Bruyère) and in the provinces, see Norbert Elias, The Court Society, trans. Edmund Jephcott (New York: Pantheon Books, 1983), 78-116, 171, 241; also 214-17 and 228-30 (the early romanticization of rural life); cf. Jacques Revel, "The Uses of Civility," in vol. 3 of $A$ History of Private Life, ed. Phillippe Ariès and Georges Duby (Cambridge: Belknap Press of Harvard University Press, 1987-91), 167-205; and Edward Muir, Ritual in Early Modern Europe (Cambridge: Cambridge University Press, 1997).

${ }^{27}$ Travel on horseback or by carriage was a rare luxury for most peoples in the outlying provinces until the nineteenth century. For most farming families, the primary domesticated animal was the ox for plowing—Gillian Tindall, Célestine: Voices from a French Village (New York: Henry Holt and Co., 1996), 29-31, 36-37, 46-47, 55-57, 62-63.

${ }^{28}$ One late eighteenth-century dictionary would define patois as "a corrupted tongue spoken all over the provinces" and would locate thirty such dialects and even more subvarieties (Tindall, Célestine, 67).

${ }^{29}$ N. M. Sutherland, The Massacre of St Bartholomew and the European Conflict, 1559-1572 (London: Macmillan, 1973), 312-46; Mack P. Holt, The French Wars of Religion, 1562-1629, 2nd ed. (Cambridge: New York: Cambridge University Press, 2005), 7698, quotation from 82. The Protestant-raised king Henri IV brought the Wars of Religion to an end with the Edict of Nantes (1598), thus introducing almost a century of official, if still somewhat limited, toleration for Protestantism. The Saint Bartholomew's Day Massacre is the culminating event in Meyerbeer's opera Les Huguenots (1836).

${ }^{30}$ Margaret M. McGowan, L'art du ballet de cour en France, 1581-1643 (Paris: Éditions du Centre National de la Recherche Scientifique, 1963), 108n. The early Christians (e.g., St. Justin) had continued to recognize-though they also condemnedthe principle that "the gods and emperors reflected elemental forces in the universe" (Elaine Pagels, Adam, Eve, and the Serpent [New York: Random House, 1988], 41-42).

${ }^{31}$ Joscelyn Godwin, The Pagan Dream of the Renaissance (Grand Rapids, MI: Phanes Press, 2002), 90-91, $149-51$. 
prominent appearances in courtly staged and quasi-staged celebrations-celebrations that were, of course, almost invariably assisted, to small or large degree, by music. Presumably, the inclusion of these "pagan" figures augmented the prestige of a ruler and his or her realm by creating analogies to earlier kingdoms and empires. In a similar spirit, royal mascarades and more elaborate official celebrations-such as during a royal tour-started to include current-day figures from distant lands: for example, individuals (sometimes courtiers, sometimes professional entertainers) costumed as East Asian princes, Turkish sultans and warriors, and barely clothed African or American "savages." 32 These foreign, and sometimes strongly exoticized, figures were generally presented as either admiring Europe's rulers or as challenging those rulers' authority. Often the foreigners were explicitly indicated as needing-or even desiring-to be brought to salvation under the banner of Christendom.

During the French royal tours of the realm, a monarch and his or her large retinue would reside in a series of cities, spending a few days or even several weeks in one city before moving on to the next. A particularly splendid réception took place in 1549—early in Henri II's reign-at Binche to welcome the regent of the Netherlands, Queen Marie of Hungary. (Binche is near Mons, in what is today southern Belgium.) These "fêtes de Binche" offered, among other spectacles, a full hour of dramatic_and partly danced-entrées alternating with staged combats. One combat set eight "savages" against eight knights. The geographic origin of the savages is not specified: perhaps they were understood as being from Africa or the New World. The knights were presumably European. ${ }^{33}$

Royal tours and court celebrations took on a new magnificence in late sixteenth-century France, "fostered"-as the cultural historian Frances Yates once put it—-by the Italianate artistry of the Queen Mother [i.e., the aforementioned Catherine de' Medici] and by the French musical humanist movement." Catherine used the tours "to impress foreigners with the splendour of the French court; to arouse loyalty to the monarchy among Frenchmen; [and] to draw together warring factions in pleasant and harmless recreations." 34

Catherine made a particularly lengthy and elaborate tour in 1564-66 with her eldest surviving son, the aforementioned Charles IX (who had taken the throne in 1560 at age ten). Their party (or parties, because the women-including the Queen Mother herself-traveled separately from the men) numbered some two thousand, including courtiers, servants, and fifteen companies of foot-soldiers, men-at-arms, and mounted cavalry. ${ }^{35}$ Unlike the native Brazilians whom Charles had encountered at Rouen when he was twelve (an occasion memorialized in Montaigne's famous essay on "cannibals"), the supposed ancients and foreigners on display in réceptions of the visiting royals on this two-year-long tour were, it seems, mostly or entirely French people in costumes and on horseback. ${ }^{36}$

\footnotetext{
${ }^{32}$ See, for example, the widely-reproduced costume design for François I as a Turk. On the passion of that monarch for dance-more specifically moresques and mascarades—see Margaret M. McGowan, Dance in the Renaissance: European Fashion, French Obsession (New Haven: Yale University Press, 2008), 132-43.

${ }^{33}$ Heartz, "Divertissement," 329, 332. Aside from a "German dance," it is not clear whether the enterers and combatants moved to music and followed any kind of rhythmic gestures or choreography, but Heartz proposes that the standard moresca tune-see Locke, Music and the Exotic from the Renaissance to Mozart, Ex. 6.2-was used for the savages (perhaps in their final sortie after the combat?). Further on the Binche festivals and their later resonances, see Strong, Art and Power, 91-95 and his Figs. 66-67.

${ }^{34}$ Yates, Valois Tapestries, 51-52. Alternatives to Yates's interpretations of the Valois tapestries are offered in Lisa Jardine and Jerry Brotton, Global Interests: Renaissance Art between East and West (London: Reaktion Books, 2005).

${ }^{35}$ Victor E. Graham and W. McAllister Johnson, The Royal Tour of France by Charles IX and Catherine de' Medici: Festivals and Entries 1564-6 (Toronto: University of Toronto Press, 1979), 6-7.

${ }^{36}$ On Montaigne and the native Brazilians brought to France by Villegagnon, see Locke, Music and the Exotic from the

Renaissance to Mozart, 88-92.
} 
A prominent theme at many of the réceptions for Charles during this tour was his wide reach as ruler and (if only by implication) the wide reach also of the church. At Troyes, a girl presented the teenaged monarch with a gold ring symbolizing, as she explained in verse, the eventual unboundedness of his reign: "We offer you service, and faithfulness, / And, if we can, all the Empire of the world." ${ }^{37}$ The grand entry of the court into Toulouse was the occasion for one of the earliest recorded comparisons of a French monarch to the "blazing and radiant Sun": an image that itself implied an ability to rule over the earth's entire surface and shed Christianity's light upon it. ${ }^{38}$

This rebirth of the militant Christian spirit, combined with tempting visions of great economic profit, expressed itself in a desire for conquest of distant lands or, as the girl in Troyes put it, Empire. This desire for empire, in France as elsewhere in Europe, was now directed, not at the Middle East (the target of the medieval Crusades) but at more distant lands, such as India, China, and the New World. For France, in particular, this included eastern and central regions of North America (e.g., eastern Canada and the Mississippi basin), certain Caribbean islands, and even-for a time-Brazil.

A procession during the Troyes séjour sought to root this surge of French expansionism in historical precedent by means of a large banner that compared Charles to the most renowned pre-Christian conqueror of distant lands: Alexander the Great. (Alexander had brought not only North Africa under Greek sway but even parts of Persia and-as noted earlier-India.) The procession in Troyes celebrated Charles's ability to maintain peace, foreseeing the happy day when the world's "Savages ... [will] place themselves under your power." ${ }^{39}$ These informative details come from the official published account of the royal progress of 1565-66, written (solely or mainly) by Abel Jouan, a courtier who had responsibility for the royal household's wine and food..$^{40}$

A similar message was conveyed during the séjour of Charles and his royal mother at Bordeaux. According to the standard modern summary of Jouan's published account, "three hundred well-armed men led twelve foreign captive Nations before the king, each Nation dressed in its fashion." ${ }^{" 1}$ One important detail in this summary, we might note, is inadvertently misleading. (Jouan, who presumably was competent at arithmetic and writing, may not have been well informed about, say, ancient history and global exploration, for he sometimes summarized matters of national and ethnic identity with insufficient accuracy.) If, as the two historians who wrote that summary plausibly conclude, the Greeks and Egyptians among these twelve costumed nations were ancient Greeks and Egyptians, rather than their current-day successors, then surely these two particular delegations were not represented-like the other ten-as foreign "captives" and, we might say, exotics. (More specifically, the Egyptians were not understood as being Muslims.) Rather, they were included as renowned civilizations and empires of the distant past that had, on this day, semi-miraculously materialized-across barriers of time and space-with the intention of rendering homage to a now-reigning monarch and his domestic and burgeoning overseas realm.

By contrast, the two historians' phrase "captive Nations" is utterly appropriate to groups that-on this same occasion in Bordeaux-stood for distant locations that various European countries were seeking to conquer, colonize, and/or convert: Turks, "Moors," Ceylonese, Brazilians, unspecified "savages," and

\footnotetext{
${ }^{37}$ Graham and Johnson, Royal Tour, 16, 15.

${ }^{38}$ Graham and Johnson, Royal Tour, 16. The image would eventually be associated particularly with Louis XIV, le Roi-Soleil.

${ }^{39}$ Quotation from the official printed account of the 1564-66 French royal tour, in Graham and Johnson, Royal Tour, 15-16; Graham and Johnson add that the savages were "of unspecified origin."

${ }^{40}$ The main text of Graham and Johnson's book (Royal Tour) consists of an untranslated but richly annotated edition of this printed account. On Jouan, see Graham and Johnson, Royal Tour, 4, 71.

${ }^{41}$ Graham and Johnson, Royal Tour, 15.
} 
"Americans"- the latter meaning members of native tribes, not European colonists. A representative of each group "made an address of loyalty to the King in his own language, which was then translated by an interpreter." ${ }^{42}$ It may well be that some (or all) of these representatives were French actors in costume, repeating a few memorized syllables: in Turkish, Arabic, Ceylonese, ancient Greek, some native Brazilian dialect, and so on. (We can only guess what the ancient Egyptians uttered.)

The frank emphasis, just seen, on the power and legitimacy of the French monarch within an increasingly world-wide context would continue for many years. In 1571 Charles (then twenty years of age) and Elisabeth of Austria, whom he had recently married, would arrive in Paris amidst a series of celebrations that were shaped by what Frances Yates calls the "theme" of France's destined "rôle of world religious leadership." Indeed, in the course of those very celebrations in Paris, a private court banquetheld in the bishop's palace- "expressed the imperial theme in terms of Bacchus, the world-conquering god of the East." ${ }^{43}$ No doubt music contributed to that occasion as well, exquisitely performed by some of the French court's ablest musicians.

\section{One Stop on a Royal Tour: Bayonne, 1565}

Every major courtly festivity had its own peculiar circumstances, and none can fully represent the others. ${ }^{44}$ Nonetheless, it will repay us to focus in some detail on one lengthy stop that occurred during the aforementioned 1564-66 tour by the young Charles IX and Queen Mother Catherine: the séjour in Bayonne, a port and fortress town in the southwest corner of France, close to the Spanish border. This lengthy stay in Bayonne has been carefully dissected by historians for its specific political ramifications but not for its portrayals of foreigners and foreignness. Gratifyingly, the events in Bayonne have the value of being documented in unsurpassed detail, thanks to Jouan's published account and two other eyewitness reports. (Unfortunately, the musical aspects of those events are rarely specified, though we can extrapolate to some extent from analogous events that occurred elsewhere in France and Italy during the late sixteenth and seventeenth centuries. For this reason, we will for the most part delay until a bit later in this article a discussion of how the events in Bayonne were supported musically.)

The royal party arrived in Bayonne over several weeks in late May and early June 1565 and stayed there nearly two months. Charles turned fifteen on 27 June. The visit to Bayonne was important in part because the Queen Mother had invited Philip II of Spain to meet her and the young French king there. She hoped to moderate Spain's determined opposition to all "heresy" (i.e., Protestantism). Philip foiled this plan by sending, in his place, Catherine's daughter, Élisabeth de Valois, who had become Philip's wife-hence queen of Spain-six years earlier, plus his trusted counselor the Duke of Alba. ${ }^{45}$ The

\footnotetext{
${ }^{42}$ Graham and Johnson, Royal Tour, 15-16.

${ }^{43}$ Frances A. Yates's summary, in her Astraea: The Imperial Theme in the Sixteenth Century (London: Routledge and Kegan Paul, 1975), 141; cf. (on Bacchus) Richard Hunter, The Shadow of Callimachus: Studies in the Reception of Hellenistic Poetry at Rome (Cambridge: Cambridge University Press, 2006), 169.

${ }^{44}$ See, for example, the discussions of various equestrian ballets in van Orden, Music; Fabbri, Musica; and three writings by Kelly A. Harness: Echoes, 142-73; "Habsburgs, Heretics, and Horses: Equestrian Ballets and Other Staged Battles in Florence during the First Decade of the Thirty Years War," in L'arme e gli amori: Ariosto, Tasso and Guarini in Late Renaissance Florence: Acts of an International Conference, Florence, Villa I Tatti, Fune 27-29, 2001, ed. Massimiliano Rossi and Fiorella Gioffredi Superbi, (Florence: Olschki, 2004) 2:255-83; and "Nata à maneggi \& essercizii grandi': Archduchess Maria Magdalena and Equestrian Entertainments in Florence, 1608-1625," in "La liberazione di Ruggiero dall'isola d'Alcina”: Räume und Inszenierungen in Francesca Caccinis Ballettoper (Florenz, 1625), ed. Christine Fischer (Zurich: Chronos Verlag, 2015), 89-108. A basic overview of the genre is provided in Helen Watanabe-O'Kelly, “The Equestrian Ballet in Seventeenth-Century Europe: Origin, Description, Development," German Life and Letters 36, no. 3 (April 1983): 198-212.

${ }^{45}$ Strong, Art and Power, 105-9. Élisabeth and Philip II are known to operagoers as leading characters in Verdi's 1867 French
} 
ceremonies went ahead, nonetheless, and a celebratory spirit was still in the air, in part because Catherine had recently succeeded in working out a successful union between her son and Elisabeth of Austria. ${ }^{46}$

The events of the Bayonne séjour were described in writing by multiple participants and observers, including Charles's very alert twelve-year-old sister Marguerite de Valois (the future wife of French king Henri IV) and at least one visiting Spaniard. Abel Jouan's aforementioned lengthy account was published in lightly differing editions in three French cities. ${ }^{47}$ All these documents agree that the doings in Bayonne were overwhelmingly elaborate. ${ }^{48}$ The rich range of surviving descriptions enables us to sense the careful planning - and conspicuous display of resources - that characterized such events.

The accounts do not, however, always agree about certain matters of detail, such as about how one or another person was costumed, a crucial matter when one today tries to assess what ethnicities were being portrayed. Such disparities in the written descriptions suggest that sometimes a certain foreign or group costume had been announced in advance-and therefore got described that way in a given document—but, when the day arrived, was replaced by another kind of costume entirely. ${ }^{49}$ For example, in a particularly grand procession scheduled for the first day of festivities (19 June, sometimes called the first Festival of the stay in Bayonne), the original plan was that the king, his brother, and noblemen of the court would arrive ready to fight in a tournament and would be dressed in a variety of costumes: Egyptian (presumably ancient), old-French, Moorish, and Spanish. The plan seems to have been scrapped at some point. Instead, male-"female" couples entered, dressed in a somewhat different range of local and foreign styles: Albanian (which presumably involved Turkish-looking robes and maybe even turbans), French, Greek (presumably ancient), Moorish, Roman (almost surely ancient), and Spanish. ${ }^{50}$ The "female" in each national couple was played by a man. Across many centuries, equestrian events were normally restricted to males, the one exception being the occasional "running at the ring" - that is, a golden ring that one caught on the tip of one's lance-such as we saw above in a case from 1581 Paris (wedding of the Duc de Joyeuse). Males regularly cross-dressed as women, but not vice-versa: e.g., in comic masques and-in certain countries, such as England-in plays generally. ${ }^{51}$

Another possible explanation for the disparities between surviving descriptions is that chroniclers were seeing the same costume but reading it differently. For example, regarding another day during the Bayonne festivities, a certain costumed group is described, in one written report, as "Tartars" and, in another, as "Scottish savages." 52

\footnotetext{
grand opera Don Carlos (often performed in Italian as Don Carlo).

${ }^{46}$ The couple would marry in 1570.

${ }^{47}$ Graham and Johnson, Royal Tour, 4. An overview of the dancing during this royal tour is in McGowan, Dance, 161-65.

${ }^{48}$ One exception: several Spanish noblemen were present who had been at the aforementioned 1549 reception for Queen

Marie of Hungary; they grumbled that what was on display in Bayonne "was nothing in comparison to las fiestas de Bains [i.e., Binche].” Heartz, "Divertissement de palais," 329, citing Brantôme, Des Dames (published posthumously in 1665-66; Brantôme died in 1614).

${ }^{49}$ Watanabe-O'Kelly cautions that the festival book, when printed in advance, more or less dictated the wording and tone of other reports that got written regardless of what actually happened during the festival; see Helen Watanabe-O'Kelly, "The Early Modern Festival Book: Function and Form," in "Europa Triumphans": Court and Civic Festivals in Early Modern Europe , ed. J.R. Mulryne, Helen Watanabe-O'Kelly and Margaret Shewring (Aldershot: Ashgate, 2004; in conjunction with the Modern Humanities Research Association) 1:3-18.

${ }^{50}$ Graham and Johnson, Royal Tour, 29-35, 307-08, 335-37.

${ }^{51}$ See n. 54 below. For the description of a 1599 parade in Württemberg, see Sabine Hesse, "Die Neue Welt in Stuttgart: Die Kunstkammer Herzog Friedrichs I. und der Aufzug zum Ringrennen am 25. Februar 1599," in Susanne Borgards and Ulrich Günther, eds., Hofkultur un 1600: Die Hofmusik Herzog Friedrichs I. von Württemberg und ihr kulturelles Umfeld (Ostfildern: Jan Thorbecke Verlag, 2010), 139-65 (here 151-64, esp. pl. 13).

${ }^{52}$ The Eastern peoples in question were mostly Mongol- and Turkic-speaking peoples living in regions south and east of Russia, e.g., in the Golden Horde. The more accurate term is Tatar (with one "r," as in the modern nation Tatarstan).
} 
The splendor and exquisite detail of many of the foreign costumes on display during the Bayonne séjour can be sensed in the following description of the entrance of an Amazon woman (actually the king's brother) during the aforementioned grand procession. Amazons were understood by the Greeks as being warlike women who lived in some distant land-for example, what is today Ukraine-and thus were one classic type of exotic population: a little known group that was fearsome yet also an intriguing inverted image of Us (in this case European women, systematically excluded from combat and other "manly" prerogatives). ${ }^{53}$ We may also note how adroitly the semi-official account navigates the tension between the gender of the character and that of the prominent individual playing her:

The Lady whom the King [Charles IX] led in was Monsieur [his brother, the Duc d'Orléans, the future Henri III] and was dressed [habillée; note the feminine ending] as an Amazon, in a robe whose sleeves were puffed out at the top with golden cloth, enriched with golden fringe, as were the covering and breast-piece of the horse. The short boots were of deep-red satin bedecked with gold fringe. ${ }^{54}$

The last of the "couples" to enter during this opening procession included the Duc de Nevers and other chevaliers, dressed as Turks or Moors (accounts vary) ${ }^{55}$ Each Turk or Moor carried a javelin "that threw fireworks from its tip." ${ }^{56}$ This brightly sparkling device may have been meant to suggest, by visual equivalence, how sharp and dangerous the weapons were. ${ }^{57}$ The threat posed by the actual Turks was surely on the minds of many in attendance that day. Over the preceding months, Ottoman troops had been attempting to seize Malta from the church-supported Knights of St. Jean. Indeed, toward the beginning of the Bayonne séjour, envoys from the sultan had met with the young French king in order to request the right to dock Ottoman military ships in one of the port cities in Provence. ${ }^{58}$

As for the actual jousting that occurred at the end of that opening procession and on other days of the Bayonne séjour, one suspects that it was kept safely in check. All present surely knew that, scarcely five years earlier, Charles's father Henri II had, during a tournament, received a sliver in his eye from the javelin of one of his trusted supporters (Gabriel, Comte de Montgomery) and had died of the resulting infection. ${ }^{59}$

According to the Oxford English Dictionary, the extra " $r$ " was added early on in Europe because of the similarity between "Tatar" and "Tartarus," i.e., Hades. Louis IX, in the thirteenth century, may have clinched the misspelling by his famous play on words advocating that the French troops "send the Ta[r]tars to Tartarus."

${ }^{53}$ The costume was not, as one might wonder, a reference to the region around the Amazon River in Brazil. The name

"Amazon" got assigned to that region and river because conquering armies from Spain and Portugal had encountered native fighters who were female-or perhaps were mistakenly taken to be female because of their appearance (further see Locke, Music and the Exotic from the Renaissance to Mozart, 169 and n. 13).

${ }^{54}$ Graham and Johnson, Royal Tour, 29-35, 307-08, 335-37 (Amazon quotation from 335). Male control of horses continued to be the norm up to the end of the eighteenth-century. Even in the waning (increasingly "frivolous" and "comic," according to Watanabe-O'Kelly) days of the carrousel tradition, the Habsburg Empress Maria Theresia and other women in various European courts did not compete on horseback but rather were carried in sledges behind horses that were driven by gentlemen, and they tilted at a ring—rather than a Turk's head—or shot at objects with pistols: Helen Watanabe-O'Kelly, "Tournaments in Europe," in Béhar and Watanabe-O'Kelly, Spectaculum europaeum, 593-639 (here 602-03).

${ }^{55}$ As noted above, the "Moor" could simply mean "Turk" (or Muslim). Sometimes, though, the terms were treated quite distinctly-for example in regard to the two masks in Figure 1, if the museum's labels can be taken as reflecting sixteenthcentury usage.

${ }^{56}$ Graham and Johnson, Royal Tour, 38.

${ }^{57}$ Or perhaps it was a reference to "Greek fire," a sticky concoction that burned anything it hit and that-because it could stay alight even on top of water-was valued as a weapon for sea battles. A century or two earlier, troops and ships from the Byzantine Empire had used Greek fire-with some success at first-to repel repeated advances by the Arabs.

${ }^{58}$ Graham and Johnson, Royal Tour, 116. Eventually the combined European forces-mainly from Spain and Italy-managed to expel the Ottomans from Malta, an event that has sometimes been described as a marking a major, indeed permanent shift in power relations throughout the Mediterranean region.

${ }^{59}$ Montgomery was captain of the king's Scots Guards. He later converted to Protestantism and became a prominent 


\section{Evidence from Music Used in Equestrian Events at Various European Courts}

From the dozens upon dozens of pages describing the 1564-66 French royal tour, we learn that some processions or other events lasted until 9 P.M. and required torches. ${ }^{60}$ But we find few hints about what kinds of music were performed during these events. One imagines-given the evidence about courtly celebrations, in general, around this time-that the music often consisted of brass fanfares or wind marches and included one or more drummers on horseback playing a pair of timpani. ${ }^{61}$

We can, though, extrapolate to Bayonne from specific information about processions, tournaments, and equestrian ballets held elsewhere. For example, in Turin, a few decades later (1608), eight ridersFrench and Italian princes costumed as Cypriot knights-dismounted and "danced to the sound of trumpets" before performing a series of patterns ("evolutions") with their swords and striking each other, or at least pretending to do so. This equestrian ballet was structured by a familiar Us/Them binarism: the Cypriot knights_Cyprus was at this time ruled by the house of Savoy (in northern Italy) — had come to set free eight noblewomen who had been taken captive by pirates. Interestingly (in the context of the present article) the Them, in this case, likely had an ethnic/foreign component: pirates, in the seventeenth century, were often portrayed as darkish-skinned Turks or North Africans, wearing an earring or sporting a colorful strip of cloth around their dark hair. ${ }^{62}$

Informative in a different way is an equestrian ballet put on by the French court in 1612, in honor of the betrothal of Louis XIII to Anne of Austria. The ballet seems not to have had any special ethnic or exotic component, but we are fortunate to have four airs that were used in it. The four tunes are relatively short; perhaps each was repeated several times. ${ }^{63}$ The manuscript of the 1612 ballet is marked "pour les grands hautbois," which implies, taken narrowly, oboes, bassoons, and perhaps drums but might as easily refer to other kinds of wind instruments (instead, or as well). A 1625 French book about how the king and his male courtiers were trained in equestrian skills includes an illustration showing mounted riders surrounded by musicians. The musicians consist of three separated small bands, totaling four trumpets, two drums, four fifes, four shawms, and two cornetti. Van Orden suggests that sackbuts were also added in such a situation, for the lowest part.

The rhythms in the four surviving musical pieces for Louis XIII's 1612 equestrian ballet are, not surprisingly, simpler and more repetitive than in dances for humans; the chords, plainer. Van Orden has

\footnotetext{
Huguenot leader. He barely escaped the massacres of St. Bartholomew's Day (1572), led a rebellion against the French crown, and was captured and executed in 1574.

${ }^{60}$ Graham and Johnson, Royal Tour, 116.

${ }^{61}$ Bruce Haynes, The Eloquent Oboe: A History of the Hautboy 1640-1760 (Oxford: Oxford University Press, 2001), 161-68 and 275-89; and Geoffrey Burgess and Bruce Haynes, The Oboe (New Haven: Yale University Press, 2004), 6-84. Late medieval and Renaissance military bands, used in tournaments and other outdoor events, had been patterned largely on those witnessed in Muslim lands during the Crusades and thus consisted of rough-toned shawms-double-reed instruments descended from the Middle Eastern zurna - plus trumpets and drums. The aforementioned Württemberg parade of 1599 included four musicians dressed in South American feathered skirts and playing crumhorns and what seems to be a bass shawm (Hesse, "Neue," 153-55, with costume sketch giving the musicians' names). Starting in the late seventeenth century, courtly and military bands began to replace shawms with the sweeter and more reliable oboes and bassoons, and these were eventually to be joined by clarinets, horns, and, finally, trumpets and other brass in the eighteenth and early nineteenth centuries.

${ }^{62}$ Watanabe-O'Kelly, “Tournaments in Europe," 616-18; see also McGowan, Dance, 118-22.

${ }^{63}$ The four pieces-a march and three branles - are written out in five-part texture in the manuscript and are transcribed in full in van Orden, Music, 274-78. David J. Buch, some years earlier, offered a (closely similar) transcription-with further discussion of the Philidor manuscript that is the main surviving source-in his Dance Music from the Ballets de Cour 15751651: Historical Commentary, Source Study, and Transcriptions from the Philidor Manuscripts (Stuyvesant NY: Pendragon Press, 1994), xvii-xviii, xx (facsimile), 25, 27, 67, and 111-15.
} 
pointed out that an arrangement of these four short pieces appeared in a reduction for lute, published by Robert Ballard (who may well have been the composer as well), and that, aside from an opening march, the pieces are in the style of a branle, "the simplest of all social dances choreographically and hence the dance with the bluntest musical idioms." ${ }^{\prime 4}$ She posits further that the branles using dotted rhythms were intended for the knights, "who had the most difficult [i.e., slower and more controlled] passages to perform" with their horse and that a branle gay in quicker triple meter was intended for the squires, whose horses performed "lower and quicker steps." ${ }^{65}$ an Orden also notes that three of the four pieces end with a passage in quick triple meter, which probably helped serve as a signal to horses and riders that this particular section of the choreography was about to come to an end. ${ }^{66}$ One can reasonably suggest that similar music may have been used for one or another of the processions and tournaments that were staged at Bayonne in 1565-some of which, as shown above, involved foreign "nations." Perhaps marches were played, many times repeated, during an entry procession, and branles were employed during jousts and tournaments, depending in part on which foreign nation was being portrayed. For example, ancient Romans - as historical predecessors of the current monarch-may have entered to grand music, whereas Moors or Albanians may at times have acted more the way that skittish, semi-comical squires tended to do.

\section{Music during Other Events in Bayonne}

Fortunately for us, the music used on various other occasions during the Bayonne séjour is given at least a few words of description. The events in question involved actors and singers playing quasitheatrical roles that were more active-more specifically defined-than the costumed, parading dukes on horseback. These quasi-theatrical roles often touched on exotic subject matter, as we might normally understand it today, i.e., distant and culturally different lands, such as "Cathay" and the Muslim-ruled territories of the Middle East. But they also alluded, often very explicitly, to varying sorts of Otherness and "difference," such as French peasant life (quite unlike that of the aristocracy), European lands outside of France (England and Ireland, in one event at Bayonne), the mythological past (e.g., Greek and Roman gods), and the supernatural more generally. Over the next few centuries, in genres such as ballet and opera, each of these four topics or "realms" would, at times, be treated as somewhat exotic_or linked with overtly exotic subject matter. Thus it may be worth seeing how they were portrayed at this early date. Furthermore, the possibility exists that the music described in these events gives clues about what was done during various equestrian events described above. Or, if the music was decidedly different, this in itself is interesting and worth noting. In any case, various events combined equestrian elements with dramatic, music, and literary ones, so it would be a mistake to try to create too sharp a distinction between the categories.

Two particularly elaborate events during the Bayonne séjour blended elements of theater, musical performance, and equestrian tournament in distinctive ways. The first of these occurred on Day Two of the festivities (21 June). This extravaganza was launched by a Fairy singing a lengthy chanson in praise of

\footnotetext{
${ }^{64}$ Van Orden, Music, 278-79.

${ }^{65}$ Van Orden, Music, 279.

${ }^{66}$ Van Orden, Music, 279. Other possible ways of writing effective music for equestrian maneuvers are demonstrated in the surviving dances written by Johann Heinrich Schmelzer for an equestrian ballet in 1666 (honoring the marriage of Emperor Leopold I to Margherita, the infanta of Spain). The 1667 edition from the court printer Matteo Cosmerovio contains a Corrente, Giga, Follia, Allemanda, and concluding Sarabanda, and is available at http://ks.imslp.info/files/imglnks/usimg/5/51/IMSLP297805-PMLP482695-arieperilballett00schm.pdf.
} 
the royals. ${ }^{67}$ In the pauses between the Fairy's stanzas, a number of people entered, costumed as rocks and orange trees (and perhaps accompanied by instrumental music). The Fairy explained that various Greek gods-and sorceresses from Ariosto's epic poem Orlando furioso- had the power to transform an individual into an inanimate object whose inherent characteristics were appropriate to how the individual had behaved. The backstory provided by the Fairy contained exotic overtones that would have been evident to any well-read person in attendance. In Ariosto's Orlando, the two primary sorceresses are pagans: Alcina, who tries to keep Ruggiero-a major warrior for the Saracen, i.e., Muslim, army-away from the Christian warrior-damsel Bradamante-and Angelica, the seductive Queen of Cathay (a vaguely defined region that could include China, Mongolia, or even India), for whom Orlando—or, in French, Rolandnearly abandons his righteous mission as Christian knight fighting the Saracens.

The audience learned through the Fairy's song that the rocks had once been knights who too stubbornly courted six "cruel and ungrateful ladies." Just as appropriately, the trees bearing oranges-a fruit that is sweet but acidic_-had once been those enticing but men-rejecting ladies. After the Fairy's sung explanations, three of the knights came back to life and, on horseback, attacked a structure representing a castle, but without success. Charles IX himself finally stormed the castle, thereby restoring peace and-as Abel Jouan's published account put it_- "making Christendom more flourishing." 68 This official interpretation-and the singer's allusion to one or more exotic sorceresses-makes clear the parallel between, on the one hand, the medieval Crusades and, on the other, two recent or current situations: Europe's recurring struggle with the Ottoman Empire and with French Protestants. (The latter had been claiming the right to worship and to be allowed political representation; their cause had found support in England and other northern European lands.)

On 25 June, the king's birthday, six deputies "from" Arthurian-era Britain and Ireland-actually, as usual, Frenchmen in costume-requested permission from the court to let a total of sixteen knights supposedly representing each of those countries settle by combat the question of whether love is a necessary basis for human wisdom and virtue (the Irish claim) or a shifting, unreliable one (the English one). The six deputies consisted of two singers, who accompanied themselves (or pretended to?) on the lyre, plus two lutenists and two violinists. The king agreed to head the English contingent; his brother, the Irish one. The combat took place outdoors, in a fenced area guarded by two thousand soldiers, and began with a procession (led by nine mounted trumpeters, who also performed on other occasions during the Bayonne visit but on this occasion wore Irish costumes) and two floats decorated with allegorical figures appropriate to the two causes. Heroic Virtue, on the first float, sang a three-strophe song praising Charles IX; nine boys dressed as Cupids (Amours), "all excellent musicians," participated, and Heavenly Love sang a "panegyric devoted to the merits of love." The combat began with jousters pairing off one-on-one, then by twos and threes, until all sixteen knights and their royal champions were on the field doing an equestrian ballet midst great noisy balls of fire that were thrown with—as one account put it—.such artifice and industry that not a single man nor horse was startled [offensé]." The two sides ended up intermingling. They thereby demonstrated that Virtue and Love were "two aspects of one ennobling sentiment." The event closed with a firework display. ${ }^{69}$

The music that we have read about thus far concerning the Bayonne séjour consisted mainly of songs,

\footnotetext{
${ }^{67}$ The performer was perhaps a castrato, as had been the case with a nymph at a royal festival in Fontainebleau before the Royal Tour began: "Ceste Nimphe estoit un jeune chastré" (Graham and Johnson, Royal Tour, 152).

${ }^{68}$ Graham and Johnson, Royal Tour, 26, 42, 344-56 (singing Fairy; castle).

${ }^{69}$ Graham and Johnson, Royal Tour, 46-54 (quotations are their summaries, except for the passage about the balls of fire).
} 
marches, and the like in the standard styles of the day. Many of these pieces were composed or adapted for the occasion, and the performances-being in the hands of the king's musicians-were on the highest level available anywhere in Europe. We know, for example, that one of the musicians participating in the Ireland-England extravaganza just described was Vaumesnil, the court's leading lutenist. ${ }^{70}$

By contrast, much of the music-making that took place on 23 June (two days before the big "England"/"Ireland" tournament) was just as captivating and skillful, but on this occasion ethnically colored, being modeled on "folk" musical traditions that had long been disseminated orally. The occasion was an organized trip, by boat, to a banquet on a nearby island. Members of court, costumed as shepherds and shepherdesses from the various provinces (of, one presumes, France), executed appropriate dances in what one of the many Spaniards in attendance described as a rustic_or shepherd-like—manner ("bailando al modo pastoril"). These supposed shepherd-folk were accompanied, the Spaniard added, by "mucha armonía de musica de muchos instrumentos." The young Princess Marguerite de Valois noted more precisely the various folk instruments: bagpipe, "village drums," and so on. ${ }^{71}$ (Bagpipers are plainly visible in a visual rendering of this scene, on one of the famous Valois Tapestries.) ${ }^{72}$ After this, three "nymphs" sang the friendship of the French and Spanish monarchs, comparing it to the closeness of "brothershepherds." Thus, the peace between the two countries was not only "celebrated in the terms of idyllic Golden Age pastoral life" (as Roy Strong puts it) ${ }^{73}$ but linked to the concrete reality of current-day peasant life and culture-at least, as close as courtiers could portray it. As for the bagpipers and drummers, perhaps the organizers had enlisted actual folk musicians for the task. Or were some of the royal musicians adept on folk instruments as well? ? $^{74}$

We are told that the Spanish guests so "marveled" and "took such great pleasure" at the French regional dancing that they kept watching till midnight. It is tempting to speculate that, like many Spaniards for centuries after, they had taken a substantial siesta during the afternoon and so had found their second wind just when the French people were heading back to the mainland to sleep. Indeed, we are told that the Spaniards who lingered longest with the dancers found that there was not enough room on the last boats and thus were obliged to spend the night on the island. ${ }^{75}$

The performances on the island — what we might call "folk" or "regional" dancing and music_may well have felt at least somewhat exotic to the Spaniards, and indeed even to many of the Parisians and other French guests from other parts of the nation than the one whose dance was being done at a given moment. It was also consistent with the fascination, widespread around this time, for music of different parts of Europe and different social classes. Many lighter-toned sixteenth-century polyphonic songs and madrigals evoked villages or distant towns whose customs and music-making were perceived as colorful

\footnotetext{
${ }^{70}$ Graham and Johnson, Royal Tour, 46-54, esp. 47.

${ }^{71}$ Graham and Johnson, Royal Tour, 29, 44 (specific folk instruments), 317. The modern Spanish word for pastoral is pastoral, not pastoril. Marguerite de Valois, of course, would in time become known to opera-lovers through one of the two leading female roles in the abovementioned Meyerbeer opera Les Huguenots. For further details on rural dancing at this and other courtly festivities, see McGowan, Dance, 102-3, 110-14 (so-called Ballet des polonais, i.e., dances of the French provinces performed for Polish visitors), and 186-92. The dancing for the Poles involved string and wind players perched in a tree, as shown in a detailed tapestry: Yates, Valois Tapestries, plate IV (nickname "Polish Ambassadors").

${ }^{72}$ Yates, Valois Tapestries, plate III (nickname "Whale").

${ }^{73}$ Strong, Art and Power, 108.

${ }^{74}$ At another point during the two-month stay in Bayonne, the royal party spent a week at nearby Saint-Jean-de-Luz and saw (to use the official wording) "girls who, in Basque style, have their heads shorn-those who are not married-and each has a tambourine, [its frame] made like a sieve with many jingles [sonnettes] in it." The girls danced two dances: the canadelles and the bendel. (Graham and Johnson, Royal Tour, 31, 119, and fig. 53, a Spanish girl with very short hair and tambourine.)

${ }^{75}$ Graham and Johnson, Royal Tour, 289.
} 
and attractively untutored. These vocal pieces included the tuneful chansons of Sermisy and Certon, Janequin's evocations of bird calls and the hunt, and, not least, the vast quantities of buoyant villanelle alla napolitana (or villotte or canzone villanesche) that poured from the musical presses of Europe between 1537 and around 1650.

By the way, the thirty-boat trip to the island that day had its musical aspects as well. The trip must have been a memorable one indeed, as it involved a run-in, under a bridge, with an undeniably exotic creature: a large supposed "whale"-une grande baleine faite artificiellement-that many of the travelers thought was real and that needed to be "killed" by men from the town before the trip could continue. This imitation-heroic act demonstrated the prowess of the important local fishing and whaling industries, and, by implication, of France's navy. It also symbolized, scholars suggest, the revival of Bayonne after the city had been set on fire by Spain eight years earlier. (The English would famously rout the Armada in 1588, ending such attacks.) The river trip and the whale are immortalized in a panel of the superb Valois Tapestries (the whale shoots two water spouts, one from each side of its head) and also in an exquisite drawing by Antoine de Caron that may have been one of the primary models for the tapestry. The Caron drawing shows two drummers and four trumpeters playing aboard a boat that is carrying guests. ${ }^{76}$

The flotilla of thirty boats also passed a strong-armed Neptune, whose song included bursts of sound from six cornetti played by Tritons, and Arion singing to his lyre, with "an excellent consort of six violins" playing between his stanzas. ${ }^{77}$

A ballet was also performed by nymphs "in" a large illuminated rock. Perhaps this means that they danced in a natural, amphitheater-like cave-opening or else, as some scholars understand the accounts, "upon" a rock (real or artificial) that had been wheeled in for the purpose. The music for this ballet was played-or mimed with silent instruments-by satyrs: half-human creatures often associated with mythical woodlands. ${ }^{78}$

\section{Bridging the Split between Music and Exotic Enactment}

Song, dance, and story were sumptuously on display throughout the French royal tour (or progress) that we have examined in some detail: the tour of Charles IX and Catherine de' Medici in 1564-66. But those elements were often separated from portrayal of the exotic, which (except for the possibly foreign sorceresses and the arguably exotic regional dancing on the picnic island) remained largely horse-related and often involved ceremonial processions or ritualized and heavily symbolic "combat." From Italy, during this same era (ca. 1550-1630), comes a case of music being more directly employed to tell an exotic tale on horseback. At a tournament (or sbarra) in Florence for the ducal wedding of 1579, three "Persian knights" claimed that Persian women were the most beautiful, thereby setting off a series of challenges to this claim by nine combatants, each preceded by "an elaborate festival car" mounted by some mythical being or remarkable creature. The events were "told by music and song."

Yet in Italy, too, exotic tale-telling often remained affixed to horsemanship and separate from the

\footnotetext{
${ }^{76}$ Yates, Valois Tapestries, plates III (nickname "Whale") and X; Graham and Johnson, Royal Tour, 415; and Strong, Art and Power, 105 (Catherine's taste for water festivals), 107-8, and Fig. 74.

${ }^{77}$ Graham and Johnson, Royal Tour, 43, 373-74. The cornetto (written as the French word cornet in the document) is a brighttoned, wooden wind instrument in which the vibrations are made by the lips, as with brass instruments.

${ }^{78}$ Graham and Johnson, Royal Tour, 45; but cf. McGowan, Dance, 164-65.

${ }^{79}$ For example, Apollo, a dolphin, and “a Maga [wise woman, female seer] riding on a fantastic beast” (Watanabe-O'Kelly, "Tournaments in Europe," 615).
} 
more elaborate resources of musical art. The Florentine carnival of 1616 featured an equestrian ballet portraying an imaginary battle by an Asian king and an African one over the love of an Indian queen. ${ }^{80}$ Many parts of this elaborate event—such as strophes by Aurora praising the Grand Duchess or Venus's eventual peacemaking between the two exotic kings-were utterly unexotic, and were carried out in song and madrigal. By contrast, the main plot, rich in exotic implications, was enacted on horseback by the Asian and African "kings" (actually Duke Cosimo II and his brother Lorenzo) and their respective entourages, with participation of live camels and superb mechanical elephants, yet surviving documents apparently make no mention of those extended interactions being accompanied by music. ${ }^{81}$ Perhaps there were, at most, the usual brass fanfares and double-reed marches.

All the courtly events in France and Italy discussed in this article reveal there to have been a sharp split between, on the one hand, artfully worked music (e.g., highly sophisticated songs) on non-exotic topics and, on the other, evocations of the exotic that were primarily visual (using at most marches and dances that were musically simple in order to help coordinate the actions of riders and horses). This gap must have suggested a tempting possibility to performers and creative artists: why not bridge the gap by using the rich resources of musical composition and performance to reinforce and extend representations of exotic Others?

The desire to portray exotic Others in new and vivid ways was paralleled at the time (the late sixteenth and seventeenth centuries) by an increasing interest, generally, in portraying characters, locales, and concrete historical situations. This occurred most notably in new literary genres such as the early novel (in France and Spain) and in full-length plays (by Shakespeare, Corneille, Racine, and Molière). During these same years, there arose new representational genres that involved music in a major way: the narrative court ballet and theatrical ballet—types that had a more or less continuous plot, unlike earlier court ballets-and (more comprehensively) opera and dramatic oratorio. These new, richly musical genres would finally bridge the yawning gap between the relatively generic (all-purpose) musical elements and the specifically exotic visual portrayals and physical enactments that had marked the various pageants, tournaments, processions, and "horse ballets."

Still, none of this should lead us to undervalue the effectiveness of a well-planned horsemanshipbased event, outfitted with music that was attention-getting or even, on occasion, as exquisite as people in seats of power could provide. As Iain Fenlon notes, even though equestrian events were "artistically less impressive" than operas and intermedi, they were "politically potent." ${ }^{~} 2$ (Intermedi were interludes performed between acts of spoken plays; they often consisted of singing, instrumental music, and/or dance and could involve simple or elaborate stage-sets. $)^{83}$

As we have seen above, numerous music-assisted portrayals and enactments of distant Others areas the saying goes_- "hiding in plain sight" in equestrian events that occurred in France, Italy, and no doubt

\footnotetext{
${ }^{80}$ Whether "Indian" here meant the Indian subcontinent, islands off the coast of southeast Asia, or some part of the New World is not clear.

${ }^{81}$ Nagler, Theatre Festivals, 126-28.

${ }^{82}$ Iain Fenlon, review of Suzanne G. Cusick, Francesca Caccini at the Medici Court: Music and the Circulation of Power, Fournal of the American Musicological Society 65, no. 1 (Spring 2012): 257-66 (257).

${ }^{83}$ Some intermedi, as music history texts frequently do not mention, were artistically more modest, consisting of such things as clown-like acrobatics, comical miming, mock swordfights, and torchlight processions. Still, many of these, too, were accompanied by music (e.g., rhythmic patterns on a drum or calls on a single trumpet). See my Music and the Exotic, 79, 16568, and 174-80. The latter pages deal with a closely related phenomenon to the intermedi: the balli that were performed between the acts of seventeenth- and early-eighteenth-century Italian operas. These operatic balli were usually danced or mimed—not sung—and involved instrumental accompaniment.
} 
elsewhere. (Nearly all the evidence that I have relied upon here comes from published scholarly studies, not from any archival digging.) As crucial components in the social, cultural, and religious power structures of their day, these exotic portrayals and enactments deserve to be studied further. Speaking as a musicologist, I also want to add that they deserve to be mentioned—or more than merely mentioned—in our music-history books, our classroom teaching, and our writings for a broader public.

\section{References}

Béhar, Pierre, and Helen Watanabe-O'Kelly, eds. Spectaculum Europaeum: Theatre and Spectacle in Europe (1580-1750). Histoire du spectacle en Europe (1580-1750). Wiesbaden: Harrassowitz Verlag, 1999.

Bouquet-Boyer, Marie Thérèse. "Les éléments marins dans les spectacles à la cour de Savoie, 1585-1628." In The Influence of Italian Entertainments on Sixteenth- and Seventeenth-Century Music Theatre in France, Savoy and England, edited by Marie-Claude Canova-Green and Francesca Chiarelli, 53-69. Lewiston NY: Edwin Mellen Press, 2000.

Buch, David J. Dance Music from the Ballets de Cour 1575-1651: Historical Commentary, Source Study, and Transcriptions from the Philidor Manuscripts. Stuyvesant NY: Pendragon Press, 1994.

Burgess, Geoffrey, and Bruce Haynes. The Oboe. New Haven: Yale University Press, 2004.

Chan, Mary. Music in the Theatre of Ben Jonson. Oxford: Clarendon Press, 1980.

Cummings, Anthony M. The Lion's Ear: Pope, Leo X, the Renaissance Papacy, and Music. Ann Arbor: University of Michigan Press, 2012. https://doi.org/10.3998/mpub.2662733.

Elias, Norbert. The Court Society. Translated by Edmund Jephcott. New York: Pantheon Books, 1983.

Fabbri, Paolo, ed. Musica in torneo nell'Italia del Seicento. Lucca: Libreria Musicale Italiana, 1999.

Fenlon, Iain. Review of Suzanne G. Cusick, Francesca Caccini at the Medici Court: Music and the Circulation of Power. Journal of the American Musicological Society 65, no. 1 (Spring 2012): 257-66.

Gaume, Maxime, ed. La triomphante entrée de tresillustre dame Madame Magdeleine de la Rochefoucaud, Espouse de hault E puissant Seigneur Messire Just-Loys de Tournon, Seigneur E Baron dudict lieu, Comte de Roussillon, Ec., Faicte en la Ville E Université de Tournon le dimenche vingtquatriesme du moys d'Avril 1583. SaintÉtienne: Presses de l'Université de Saint-Étienne, 1976. Facsimile edition of the 1583 edition (Lyons: Jean Pillehotte).

Geertz, Clifford. Local Knowledge: Further Essays in Interpretive Anthropology, $3^{\text {rd }}$ ed. New York: Basic Books, 2000.

Godwin, Joscelyn. The Pagan Dream of the Renaissance. Grand Rapids, MI: Phanes Press, 2002.

Graham, Victor E., and W. McAllister Johnson. The Royal Tour of France by Charles IX and Catherine de' Medici: Festivals and Entries 1564-6. Toronto: University of Toronto Press, 1979.

Harness, Kelly A. Echoes of Women's Voices: Music, Art, and Female Patronage in Early Modern Florence. Chicago: University of Chicago Press, 2006.

- "Fighting for Relevance: Guerra d'amore and Florentine Colonial Aspirations in the First Decades of the Seventeenth Century." Presentation at the 16th Biennial International Conference on Baroque Music, Salzburg, Austria, July 2014.

- "Habsburgs, Heretics, and Horses: Equestrian Ballets and Other Staged Battles in Florence during the First Decade of the Thirty Years War." In L'arme e gli amori: Ariosto, Tasso and Guarini in Late 
Renaissance Florence: Acts of an International Conference, Florence, Villa I Tatti, June 27-29, 2001, edited by Massimiliano Rossi and Fiorella Gioffredi Superbi, 2:255-83. Florence: Olschki, 2004.

. "Nata à maneggi \& essercizii grandi': Archduchess Maria Magdalena and Equestrian Entertainments in Florence, 1608-1625." In "La liberazione di Ruggiero dall'isola d'Alcina": Räume und Inszenierungen in Francesca Caccinis Ballettoper (Florenz, 1625), edited by Christine Fischer, 89-108. Zurich: Chronos Verlag, 2015.

Haynes, Bruce. The Eloquent Oboe: A History of the Hautboy 1640-1760. Oxford: Oxford University Press, 2001.

Hesse, Sabine. "Die Neue Welt in Stuttgart: Die Kunstkammer Herzog Friedrichs I. und der Aufzug zum Ringrennen am 25. Februar 1599." In Hofkultur un 1600: Die Hofmusik Herzog Friedrichs I. von Württemberg und ihr kulturelles Umfeld, edited by Susanne Borgards and Ulrich Günther, 139-65. Ostfildern: Jan Thorbecke Verlag, 2010.

Heartz, Daniel. "Un divertissement de palais pour Charles Quint à Binche." In Fêtes et cérémonies au temps de Charles Quint, edited by Jean Jacquot, 329-40. Vol. 2 of Les Fêtes de la Renaissance. Paris: Éditions du Centre national de la recherche scientifique, 1960.

Holt, Mack P. The French Wars of Religion, 1562-1629, 2nd ed. Cambridge and New York: Cambridge University Press, 2005. https://doi.org/10.1017/CBO9780511817922.

Hunter, Richard. The Shadow of Callimachus: Studies in the Reception of Hellenistic Poetry at Rome. Cambridge: Cambridge University Press, 2006. https://doi.org/10.1017/CBO9780511618499.

Jardine, Lisa, and Jerry Brotton. Global Interests: Renaissance Art between East and West. London: Reaktion Books, 2005.

Locke, Ralph P. "Alexander der Grosse und der indische Raja Puru: Exotik in einem Libretto Metastasios und in darauf basierenden Opern von Hasse und von Händel." Translated by Michelle Miles and Ingo Maerker. In Fremde Helden auf europäischen Bühnen 1600-1900, edited by Achim Aurnhammer and Barbara Korte. Vol. 6 in the series Helden-Heroisierungen-Heroismen. Würzburg: Ergon, 2016, 27-44. An Italian version, "Alessandro Magno e il Ragià indiano Puru: Esotismo in un libretto di Metastasio nelle realizzazioni di Hasse e Handel," translated by Luana Salvarni, has appeared in Musica/Realtà, no. 110 (July 2016): 99-123. My original English-language version, which includes a section omitted from the translated version, is now available as "Alexander the Great and the Indian Rajah Puru: Exoticism in a Metastasio Libretto as Set by Hasse and by Handel," Revue de musicologie 102 (2016), no. 2, pp. 275-318.

- Music and the Exotic: Images and Reflections. Cambridge: Cambridge University Press, 2009. - Music and the Exotic from the Renaissance to Mozart. Cambridge: Cambridge University Press, 2015. https://doi.org/10.1017/CBO9780511998157.

- "Race and Slavery in Mozart Operas: A Letter to the New York Times." In this short article, in the online arts magazine New York Arts, I include in full—and explain further-a letter that I wrote to the Times but that the newspaper did not print. My letter discusses an article by Zachary Woolfe and focuses on Die Entfïhrung aus dem Serail and Die Zauberflöte. The blog's editor, Michael Miller, prefaces my article with an informative introduction and adds some relevant links. http://newyorkarts.net/2016/08/race-slavery-mozart-operas-letter-new-york-times/\# fnref-26144-2 The letter itself was reprinted, with a brief introduction, on Norman Lebrecht's blog: http://slippedisc.com/2016/08/a-musicologist-gently-castigates-the-ny-times-music-chief/ and at the Musical America Global site: http://www.musicalamerica.com/news/newsstory.cfm?storyID=36716\&categoryID=1.

McGowan, Margaret M. L'art du ballet de cour en France, 1581-1643. Paris: Éditions du Centre national de la recherche scientifique, 1963. 
. Dance in the Renaissance: European Fashion, French Obsession. New Haven: Yale University Press, 2008.

Mikusi, Balázs, et al. "Wolfgang Amadé Mozart: K. 331 Sonata in A Major." [A report on discoveries made in 2014 re: manuscript structure and date of composition.] National Széchényi Library, Budapest. http://mozart.oszk.hu/index_en.html\#home.

Muir, Edward. Ritual in Early Modern Europe. Cambridge: Cambridge University Press, 1997.

Nagler, A. M. Theatre Festivals of the Medici, 1539-1637. Translated by George Hickenlooper. New Haven, Yale University Press, 1964.

Pagels, Elaine. Adam, Eve, and the Serpent. New York: Random House, 1988.

Ravelhofer, Barbara. The Early Stuart Masque: Dance, Costume, and Music. Oxford: Oxford University Press, 2006.

Revel, Jacques. "The Uses of Civility." In Passions of the Renaissance, ed. Roger Chartier, trans. Arthur Goldhammer. Vol. 3 of A History of Private Life, Phillippe Aries and Georges Duby, general eds., 167205. Cambridge, MA and London: Belknap/ Harvard University Press, 1989.

Sheppard, W. Anthony. "Exoticism," $2^{\text {nd }}$ ed. In Oxford Bibliographies in Music. Last modified February 25, 2016. http://www.oxfordbibliographies.com/view/document/obo-9780199757824/obo9780199757824-0123.xml?rskey $=$ hA78AR\&result $=45$.

Shewring, Margaret, ed. Waterborne Pageants and Festivities in the Renaissance: Essays in Honour ofJ. R. Mulryne. Farnham: Ashgate, 2013.

Strong, Roy. Art and Power: Renaissance Festivals, 1450-1650. Woodbridge: Boydell Press, 1984.

Sutherland, N. M. The Massacre of St Bartholomew and the European Conflict, 1559-1572. London: Macmillan, 1973.

Tindall, Gillian. Célestine: Voices from a French Village. New York: Henry Holt and Co., 1996.

van Orden, Kate. Music, Discipline, and Arms in Early Modern France. Chicago: University of Chicago Press, 2005. Van Orden organized a modern reconstruction of an equestrian ballet (2000, performed again in 2002). A one-minute video excerpt can be viewed at the website for van Orden's book: http://press.uchicago.edu/ucp/books/book/chicago/M/bo3533738.html. A four-minute video of the same event can be viewed at http://music.fas.harvard.edu/kvanorden.html (link is in the bottom line of text). The music heard in these videos is not drawn from the four surviving pieces that are discussed in the present article and that were used in the 1615 equestrian ballet.

Watanabe-O'Kelly, Helen. "The Early Modern Festival Book: Function and Form.” In J.R. Mulryne, Helen Watanabe-O'Kelly and Margaret Shewring, eds., "Europa Triumphans": Court and Civic Festivals in Early Modern Europe, vol. 1, 3-18. Aldershot: Ashgate, 2004 (in conjunction with the Modern Humanities Research Association).

- "The Equestrian Ballet in Seventeenth-Century Europe: Origin, Description,

Development." German Life and Letters 36, no. 3 (April 1983): 198-212.

https://doi.org/10.1111/j.1468-0483.1983.tb00283.x.

__. "Tournaments in Europe.” In Béhar and Watanabe-O’Kelly, Spectaculum europaeum, 593-639.

_. Triumphal Shews: Tournaments at German-Speaking Courts in Their European Context 1560-1730. Berlin: Gebr. Mann Verlag, 1992.

Whaples, Miriam K. "Early Exoticism Revisited." In Jonathan Bellman, ed., The Exotic in Western Music, 325, 307-13. Boston: Northeastern University Press, 1998. 
Yates, Frances A. Astraea: The Imperial Theme in the Sixteenth Century. London: Routledge and Kegan Paul, 1975.

. "Poésie et musique dans les 'Magnificences' au mariage du duc de Joyeuse, Paris, 1581." In Musique et poésie au XVI siècle: Paris 30 juin-4 juillet 1953, 242-64. Paris: Centre national de recherche scientifique, 1954.

—. The Valois Tapestries. London: Warburg Institute, University of London, 1959.

\begin{abstract}
In Europe, during the Early Modern Period (ca. 1500-1800), lands and peoples that were located far away were often perceived, by inhabitants of a European land, as somehow exotic: that is, as different from "Here" and "Us." Rarely mentioned in discussions of "music and the exotic" are certain important and highly formalized events that were put on by major European courts, that mainly occurred out of doors, and that often made use of horses: namely processions (often pageant-like), jousts, tournaments, and equestrian ballets. Several French and Italian courts represented the exotic Other in distinctive ways at such events. A notable series of events took place in 1565 during the politically fraught visit of the young French king Charles IX and his mother, Catherine de' Medici, to Bayonne. Detailed accounts of the Bayonne séjour reveal instances in which foreigners were portrayed, including Turks, "Moors," American "savages," an Amazon warrior (from an unknown distant land), and legendary sorceresses from Syria and Cathay, and also rural French villagers (arguably a "foreign" group, from the viewpoint of Paris-based aristocrats and their Spanish guests). These portrayals reflected struggles among the major European powers over religion, territory, and overseas empire and struggles between Europe and the Ottoman Empire over control of the Mediterranean and Eastern Europe.
\end{abstract}

